\title{
SOCIAL AWARENESS AND RESPONSIBILITY IN CONTEXT OF POLISH SERVICE COMPANIES
}

doi:10.2478/czoto-2021-0028

Date of submission of the article to the Editor: $30 / 11 / 2020$

Date of acceptance of the article by the Editor: 21/03/2021

\author{
Magdalena Bsoul- Kopowska ${ }^{1}$ - orcid id: 0000-0002-6167-6827 \\ ${ }^{1}$ Czestochowa University of Technology, Poland
}

\begin{abstract}
Companies operating on the market have to cope with a variety of crisis situations which may adversely affect their development and jeopardise the achievement of their objectives. A crisis situation may, on the one hand, have a negative impact on the development of the company, but, on the other hand, it may provide a stimulus and have a constructive effect on its functioning. One of the factors influencing the ability to function of a business, including crisis situations, is its organisational culture. Therefore, a company responding to the situation should assess the conditions both in its environment and inside it and verify the artefacts, the system of values and the main principles that are the basis for building an organisational culture. Many companies that are dealing with a crisis situation decide to undertake a conscious process of cultural transformation. However, it requires the management to take appropriate actions and the time of a crisis situation is a test for many companies - whether in such a difficult moment something can still be done with the organisational culture, or whether the entrepreneurs can only wait for its inevitable impact on the functioning of the company. The subject of this article is the impact of a crisis situation on changes occurring within the organisational culture. The study attempts to evaluate the role of organizational culture in crisis situations based on the current state of knowledge and crisis events related to COVID-19.
\end{abstract}

Keywords: organisational culture, enterprise, crisis situation, management, pandemic.

\section{INTRODUCTION}

The importance of organisational culture and its impact on the functioning of the company is particularly strong in various crisis situations it must face. In such difficult circumstances, it is organisational culture that makes the individual involvement of employees, their mutual cooperation, identification with the company form a mechanism that coordinates actions, directing them towards a common goal. The significance of creativity grows, new solutions appear, additional effort and independent thinking, which replaces waiting for instructions from supervisors. Such attitudes were already visible before, for example, during the economic crises of the early 2000s. Sudden, unexpected challenges faced by large corporations have shown 
the critical importance of company culture. Those, who had established a culture with an inbuilt ability to react to change, an internal system capable of adapting, were able to switch to self-control. Employees scattered all over the world immediately began to communicate changes in their environment to headquarters, and came out with local initiatives where necessary, based on clear, shared understanding and acceptance of values. Almost immediately, these companies were able to assess the situation, coordinate their actions on a global scale and implement measures in response to emerging and unexpected challenges. At the same time, many of the large corporations with an organisational culture unprepared for the crisis did not manage to assess the situation correctly. They acted chaotically or did not react at all, and suffered heavy losses as a result (www.ican.pl).

In November 2019, the pandemic of the infectious COVID-19 disease caused by the SARS CoV-2 coronavirus began. On 4 March, the first case of COVID-19 infection was found in Poland, which had a significant impact on the functioning of companies. In the last days of March 2020, entrepreneurs suspended their business activity en masse and informed labour offices about planned group layoffs. Due to the coronavirus epidemic and restrictions introduced by the government, just by 31 March this year, 1353 entrepreneurs closed their businesses in Poland and as many as 9151 suspended business activity. These numbers are twice as much as in the same period last year. Every fifth company plans to lay off $20 \%$ of its employees, and every tenth company plans to lay off $30 \%$. In total, as many as $66 \%$ of companies are planning some reductions in employment. Entrepreneurs also do not count on the government's anti-crisis shield as, according to many experts, it does not solve the largest problems that entrepreneurs have to face nowadays. As many as $78 \%$ of entrepreneurs consider the solutions adopted in the anti-crisis shield as very bad $(54 \%)$ or bad (24\%). Only $7 \%$ of them consider them to be good (www.polskatimes.pl).

\section{THE CONCEPT OF ORGANISATIONAL CULTURE - THEORETICAL BASIS}

Culture is a concept that has many meanings and is understood as the degree of achievement of excellent precision and efficiency in a given specialisation. Culture is also defined as the entirety of the material and mental output of the humankind, which is collected and passed on from generation to generation (Kisielnicki, 2005). The term "organisational culture" saw first use in the period of development of the human relations discipline. It referred to, among others, the cooperation of people for the effective functioning of the enterprise.

E. Mayo was one of the first to draw attention to the issue of culture when describing the experiment in the Hawthorne plant, where the creation of a work culture was noticed. In the fifties, a concept for the development of the organisation was created, which considered culture to be the source of this development. This was due to research carried out in 1952 by Kroeber and Kluckhohn, who analysed approx. 200 definitions of culture, considering those used in sociology, psychology, and other

disciplines. On this basis, they formulated a common definition for all searches for the content of this artificial reality in which we live as members of society. According to it, culture consists of models of ways of thinking, feeling and responding, acquired and transmitted mainly through symbols which, together with their incarnation in human creations, are significant achievements of human groups; the core of culture is constituted by traditional ideas and especially related values (Kroeber and Kluckhohn, 
1952). In turn, in the 1960s, R. Blake and J. Mounton used the notion of the so-called organisational climate to describe phenomena that are synonymous with organisational culture (Kożusznik, 2011). A significant step in the development of organisational culture was also taken by the American sociologist P.M. Blau 34, who described the process of shaping formal and informal organisations and thus observed the mechanism of "acquiring" culture. On the other hand, M. Allvesson and P.O.Berg, on the basis of an attempt to summarise and synthesise the development of the concept of organisational culture, believed that the concept of organisational culture first appeared in a 1951 publication by E. Jaques, "The changing culture of a factory" (Allvesson and Berg, 1992). However, the year 1974, when M. Pettigrev's article was published, is considered to be the date of appearance of the concept of culture in relation to an organisation. He defined culture as a system shared by people, providing a reference framework accepted by all members of the group at a given time. Culture is expressed through a system of conditions, categories, images that enable interpreting a situation through one's own perception (Pettigrew, 1979). The issue of organisational culture was particularly intensively studied in the 1980s, as a result of the success of Japanese companies and the development of companies establishing new subsidiaries and branches in other countries. Such a dynamic growth of interest in the issues of organisational culture in those years was influenced by such phenomena as:

- Searching for the sources of success of the Japanese economy and the origins of the crisis of the American and Western European economies at the turn of the 1970 s and 1980s. Comparative analysis has shown that the main distinguishing factor in these economies are people management methods. The extraordinary attention to the system of values and standards of Japanese companies was noticed. Very significant cultural differences were brought to attention and their importance and impact on the effectiveness of the organisation began to be recognised. The organisational culture has proven to be an important factor in management.

- After a period of domination of quantitative methods in organisational research, a return to qualitative methods is visible. It was noticed that phenomena that could not be measured by mathematical and statistical models could still be described, explained, and understood. The so-called soft, non-measurable areas of the organisation were studied.

- In a prolonged crisis of traditional management methods, theoreticians and practitioners began to look for success factors. According to T. Peters and R. Waterman, a strong and coherent organisational culture is an essential feature of a perfect company.

- M. Allvesson and P.O. Berg also drew attention to social factors: the increase in interest in symbolism and mythology by societies at the turn of the 1970s and 1980s; shifting the emphasis from the functional to the individual, unique and expressive (Czerska, 2003, Koźmiński and Piotrowski, 1999).

The ambiguity of the concept of organisational culture is determined by the multiplicity of meanings of both words - culture and organisation alike. Culture can be considered in evaluative or non-evaluative terms. Organisation, however, can be considered in the material, functional and attributive sense. It provides multiple possible interpretations of these concepts and, at the same time, the organisational culture itself. Therefore, there is a lack of unanimity among theoreticians and representatives 
of different scientific disciplines in defining and understanding the culture of an organisation. For example, in sociology and psychology, organisational culture is most often understood in a non-evaluative manner. Such a perception of culture means that it is defined through the lens of norms and patterns characteristic of a given community, which distinguish it from others (Sikorski, 1988). On the other hand, among the theoreticians of organisation and management, the prevailing approach to culture is evaluative - mentions of "high" or "low" organisational culture are commonplace and there is no uniform concept of organisational culture. L. Smircich. distinguished two basic approaches to organisational culture. The first, treating organisational culture in a functionalist manner, as an element of the "organisational environment" or as an element of the "organisational system". The second approach treats organisational culture as a useful source of analogy of organisational processes, facilitating their interpretation (Jemielniak, 2002).

\section{REVIEW OF THE DEFINITIONS OF ORGANISATIONAL CULTURE}

Such a broad understanding of culture makes it impossible to provide a clear definition within this approach. The lack of consent of researchers as to organising the approaches to organisational culture, as well as the description of its components, typologies, and relationships with other spheres of the organisation and with the environment results in multiple different definitions of organisational culture. This number of definitions is also due to the complexity of the issue of organisational culture. As it covers such sciences as sociology, psychology or management, these definitions may relate to different perceptions of the organisational culture of thinking, the way of acting, as well as whether they treat the organisation as a core metaphor or as a resource. Below is an attempt to present the most important definitions of organisational culture. One of the more general and holistic definitions was proposed by $\mathrm{M}$. Bower, who described organisational culture as "the way we do everything here" (Lundy and Bowling, 2001). This definition illustrates the scope of activities for the members of the organisation and demonstrates that it is the behaviour of individuals that shapes the organisational culture. Such a representation of culture is close to the image of it as a core metaphor showing that everything that happens in an organisation is created by human experience. Organisational culture is treated in a similar manner by: L. Smircich and C. Geertz. They see culture as "networks of meanings woven by persons in the process of organising". They believe that thanks to this understanding of organisational culture, members of a given organisation can process the reality they are exposed to through a cultural frame of reference (Smircich, 1983; Geertz, 1975; Stańczyk, 2008). P.M. Blau treated organisational culture as a set of peculiar, unwritten "rules of the social game" in an organisation that allow participants in social life to understand the organisation and identify with it (Blau, 1968). J. van Maanen, perceived organisational culture as knowledge shared to a greater or lesser extent by members of an organisation, expressed in actions and words, which the field researcher must interpret and not treat as given (van Maanen, 1988). Meanwhile, for R. Deshapande, R. Parasurman, organisational culture is an unwritten, often subconsciously perceived principle that fills the gap between what is unwritten and what actually happens in the organisation (Deshapande and Parasurman, 1987). E. Schein treats organisational culture as a model of shared, fundamental assumptions that a given group has created, solving problems of adaptation to the environment and internal integration. This formula can be 
considered as binding and is being taught to new members as the correct way to solve problems (Schein, 1992). The definition of E. Schein also shows that culture is developed and shaped by the members of the organisation and indicates the direction for new employees. Schein also draws attention to the universality of culture, and more specifically - to the similarity of problems that affect both national, ethnic, and organisational cultures (Martins and Terblanche, 2003). Although they may be different in all groups, in the context of achieving a competitive advantage, culture can become a distinguishing feature of an organisation (Acar and Acar, 2012). The role of norms and values and beliefs commonly accepted in an organisation, which constitute a system, is emphasised in the definition of organisational culture by $\mathrm{H}$. Schenplein (Schenplein, 1988). Also G. Hofstede describes the organisational culture as "programming the minds" of the members of the organisation, i.e. a set of values, norms and organisational rules effectively instilled by the group (Hofstede, 2000,). In turn, according to E. Jacques, organisational culture is a customary or traditional way of thinking and acting, which is to some extent shared by the members of the organisation and which new employees must at least partly accept (Jacques, 1952). In this definition - unlike the definition of E. Schein - organisational culture is presented as a way of thinking and acting that is shared by the members of the organisation and, in addition, they must at least partly accept it. This means that the values and standards of an individual must, at least in part, coincide with those of the entire organisation.

A review of the definitions presented above shows their multiplicity and differences in approach to organisational culture. Thus, it indicates the complexity of the concept of organisational culture and its multidimensional nature. However, regardless of how it is perceived, it can be: shaped both consciously and unconsciously by the members of the organisation, constitute a set of shared beliefs influencing the individual perception of the organisation, be holistic and unique, express the understanding of values, norms and assumptions by the members of the organisation, be created on the basis of the common experience of the members of the organisation, as it is a collective phenomenon, create rules and instruments for proceeding and solving problems and be shaped in a continuous manner.

\section{RESEARCH METHODOLOGY}

Sources and causes of crisis situations may come from inside the company as well as from its surroundings. A crisis situation affects the company to varying degrees. Some businesses are directly affected, with adverse consequences, others are affected indirectly and only very few are not affected entirely. The crisis situation causes companies to be more aware of the problem of uncertainty, unpredictability and instability in the economy (Orłowski et al., 2010). For the purposes of this article, a crisis situation shall be understood as a period in the life of an organisation in which a process of destabilisation of its functions begins and continues, leading inevitably to its collapse, however if remedial action is taken, the destabilisation of the functions of the organisation may be interrupted and the organisation may return to its next normal state.

An important rolein overcoming these situations is played by a proper organisational culture. One example is its current significance in the COVID-19 pandemic. It is the involvement of subordinates, their cooperation and proper identification with the company that allows for good change management and helps the company to survive 
a difficult period. Therefore, the current situation poses many new challenges for HR departments. The manner of performing work duties was changed by the pandemic. Remote work is now very popular. All this requires changes in the organisational culture and the application of innovations that will support the future state of the company. Therefore, during a pandemic, it becomes an important part of the organisational culture to ensure that employees are supported in the various areas of their needs by providing them with access to benefits that have a positive impact on their health and well-being in a crisis situation (https://poradnikprzedsiebiorcy.pl)

For the purposes of this article, the typology of culture proposed by K. Cameron and R. Quinn was used. They proposed a two-dimensional model of competing values, where one dimension is characterised by flexibility and freedom of activity as well as stability and control, and the other dimension represents orientation towards internal affairs as well as integration or orientation towards the position in the environment and diversity. The juxtaposition of these two dimensions made it possible to distinguish four types of cultures: clan, adhocracy, market, and hierarchy.

The purpose of this study is to attempt to answer the question of how COVID-19 affects the organisational culture of companies. This article will attempt to answer the following questions:

- Does a crisis situation, such as COVID-19, change the set of norms and values that have so far been in force in the studied companies?

- Is organisational culture still important in a pandemic?

- Will the so-called "new normal" bring a new organisational culture after the pandemic?

- What changes enforced in companies by the current COVID-19 situation will remain for a longer period?

For the purposes of the study, the following hypotheses have been adopted in this article:

- The right organisational culture in management plays a key role in times of crisis.

- The organisational culture in a pandemic must focus as much as possible on supporting the employees.

- Organisational culture cannot remain "rigid" and unchanged in the era of a changing reality.

- Only those companies that have established a culture with a built-in ability to react to change and an internal system capable of adapting to crisis situations will survive the COVID-19 pandemic.

In order to provide answers to the questions and research hypotheses raised, a questionnaire survey was used. The main study was preceded by a pilot study, which helped to eliminate questions less relevant to the problem under investigation. The final version of the survey consisted of: a description of the study and 21 closed questions with the option of individual description, in case of lack of adequate answer. The survey was divided into four parts. The first part of the survey concerned companies that were in a crisis situation even before the COVID-19 pandemic and what did the situation refer to. A diagnosis of organisational cultures of the surveyed companies was also made. The second part referred to the issues of managing a company in a situation caused by a pandemic and the most important problems they had to face. The third part dealt with the most important future challenges for companies as related to organisational culture. The last part included questions about 
the personal information of the respondent. The survey, due to the pandemic, was conducted by means of telephone questionnaire interviews and online surveys, which were sent out by e-mail. During the implementation of the survey (from May 2020 to July 2020), 45 interviews were conducted among companies from the Silesian Province, out of which 27 companies agreed to take part in the survey and underwent positive verification.

For the analysis of the collected research material and graphic presentations, Microsoft EXCEL and WORD computer software and the STATISTICA 13.3 statistical software package were used.

\section{RESEARCH RESULTS}

In the surveyed group of companies, the largest group was small companies (from 10 to 49 employees) - 65.4\%, medium-sized companies (from 50 to 249 employees) $24.8 \%$ and micro companies (up to 9 employees) $-9.8 \%$. The largest number of the surveyed businesses declared to be involved in services - $51.2 \%$, followed by manufacturing $-29.3 \%$, retail $-12.6 \%$ and wholesale $-6.9 \%$. The results of own research indicate that almost half of the surveyed companies (49.2\%) found themselves in a crisis situation at least once. Statistical analysis of the data showed a statistically significant difference between the size of a company and being in a crisis situation. In the case of micro companies, the vulnerability to a crisis situation is as follows: $62.4 \%$ - were vulnerable, $37.4 \%$ - were not vulnerable; in the case of small companies: $53.4 \%$ - were vulnerable, $46.6 \%$ - were not vulnerable; and in the case of medium-sized companies: $35.8 \%$ were vulnerable and $64.2 \%$ were not vulnerable. Therefore, it can be assumed that the smaller the company, the greater the vulnerability to crisis situations.

So far, in the times before the pandemic, in the surveyed companies, a crisis situation was most frequently manifested by: decrease in sales $(38.7 \%$ - in the case of micro companies, $32.4 \%$ - in the case of small companies and $28.9 \%$ - in the case of medium-sized companies); decrease in the market share $(19.2 \%$ - in the case of micro companies, $17.4 \%$ - in the case of small companies $-23.3 \%$ - in the case of medium-sized companies), deteriorating work atmosphere $(18.2 \%$ - in the case of micro companies, $16 \%$ - in the case of small companies and $21.2 \%$ - in the case of medium-sized companies) or loss of financial liquidity $(17 \%$ - in the case of micro companies, $15.4 \%$ - in the case of small companies and $12.2 \%$ - in the case of medium-sized companies). Of the companies surveyed, only $8.4 \%$ indicated deteriorating company image. In contrast to the crisis situations the surveyed companies had faced before, the COVID-19 pandemic was a completely new phenomenon for them and was considered unpredictable by the vast majority of companies.

Closed borders, large losses in the economy and problems, both in terms of supplies and transport restrictions, have had a significant impact on the changes in the functioning of the company and, consequently, on the decrease in its revenue. This forced companies to look for savings, which manifested in employee layoffs $-36 \%$; "cost optimisation" by withholding pay raises $-62 \%$ or lowering salaries $-44 \%$. Some companies sent their employees on unpaid leave $-24 \%$.

On the other hand, the businesses took measures to minimise the risk of COVID-19 infection among their employees and customers. The respondents indicated the following actions taken by their employers: informing about the risk of COVID-19 
infection - 59\%, proper preparation of workstations - 56\%, limiting direct contacts $46 \%$. Interestingly, $23 \%$ of the respondents indicated assistance in childcare during the working hours of the parents, $7 \%$ of companies provided psychological support for those in need and $3 \%$ - assistance in shopping.

The results of the study show the importance of organisational culture for the functioning of the company and the situation caused by the pandemic has become a test of the norms and values in force.

For this purpose, an attempt was made to diagnose the organisational culture in the surveyed companies. Taking into account the organisational culture model proposed by Quinn and Cameron, cultures dominant in the surveyed companies were identified. The conducted research showed that the culture of hierarchy is in the first place $32.4 \%$, followed by the culture of hierarchy and clan $-30.1 \%$, the third place was taken by the culture of clan $-13 \%$, the culture of the market was indicated by $9 \%$ of the respondents, the culture of hierarchy and market $-8 \%$, the culture of adhocracy $6 \%$; other options were indicated by $1.5 \%$ of the respondents. Therefore, taking into account only the dominant type of organisational culture in the surveyed businesses, we can see that qualities related to hierarchical culture are a majority (32.4\%).

In a situation where it could not be clearly stated which of the cultures dominated (arithmetic averages were the same), an additional, mixed type of organisational culture was created. This group of companies is made up of those with a very strong hierarchy and clan culture simultaneously (30.1\%). Another type of organisational culture that is important for the entire sample is clan culture. Although only $13 \%$ of the companies were identified as such, when taking into account mixed cultures (hierarchy and clan), it can be observed in more than one in three companies. Other types of cultures dominate in $10 \%$ of companies.

In medium-sized companies, the culture of hierarchy is most often the dominant one $55.4 \%$, followed by the culture of hierarchy and clan $-36.2 \%$, the culture of clan $-6 \%$ and the remaining cultures $-2.4 \%$. In small companies, the culture of hierarchy and clan is most often the dominant one $-48.4 . \%$, next was the culture of hierarchy $32.5 \%$, the third place was taken by the culture of clan $-16 \%$, the remaining cultures $-3.1 \%$. In micro companies, however, the results are as follows: hierarchy and clan $38 \%$, hierarchy $-25.4 \%$, clan $-24.6 \%$, other cultures $-12 \%$.

It is in very rare cases that we can speak of only one dominant culture in an organisation. It can be observed that the culture of hierarchy dominates, but there are also other culture types. Most often the literature on the subject mentions the domination of two types of cultures, although in every company there are features characteristic for all types.

A proper organisational culture in management plays a key role in crisis situations, including a pandemic. The current situation presents new challenges for HR management. Due to the pandemic situation, the way of performing work-related duties has changed - a significant part of companies have switched to remote work, which in turn requires changes in organisational culture and the application of innovations that will support the future state of the company. It should also be remembered that as a result of the crisis and the related state of uncertainty, the hierarchy of the expectations of employees also changes. Therefore, the surveyed companies undertake activities aimed at reinforcing their organisational culture by increasing the responsibility of employees for the organisation (36.7\%), building an atmosphere of support and trust (32.4\%), increasing the awareness of employees of 
the surveyed businesses (12.5\%), showing the possibility of implementing new solutions in the company and indicating their usefulness (10.2\%). Attention was also drawn to the new rules of functioning in the company $(4.4 \%)$ and contact with customers $(3.8 \%)$.

COVID-19 has unfortunately significantly increased the level of stress and anxiety among the employees. The current situation shows the importance of implementing sustainable and inclusive mental health policies at the workplace. This is confirmed by the research conducted for the purpose of this article. Among the answers given, the most common were: ensuring a sense of employment security $-42.4 \%$; need for open communication $-35.8 \%$; offering more flexibility to employees $-14.6 \%$; and remembering the individual needs of employees $-7.2 \%$.

After the analysis of the results, it can be concluded that in the case of the surveyed companies, micro companies showed the best response to the pandemic - as many as $68 \%$ of the surveyed considered that the actions taken by the employer were sufficient. In the case of medium-sized companies, the result was $56 \%$ and small companies $-53 \%$.

From the survey, the dominant trend in the organisational culture of the surveyed companies can be seen. It turns out that the pandemic is best handled by companies with a hierarchy and clan culture, followed by companies with a hierarchy culture.

\section{DISCUSSION}

The COVID-19 pandemic had quite a significant impact on the level of stress and anxiety among employees, which in turn contributed to the need for changes in the HR policy pursued so far. First of all, in order to survive, business managers have taken measures to implement tools that enable flexible working models and focus on an organisational culture that promotes caring for each other. In the first weeks of the pandemic, it became apparent how crucial it is to know how to take care of employees who are exposed to long-term stress, anxiety, or depression. Also due to the changes associated with the transition to remote work, it has become necessary to take into account the different needs of employees, depending on their gender, age and relationship status. Thus, respect has become even more important in the employeeemployer contacts. Another issue was the fears and prejudices against persons of other nationalities, who could be seen as groups with a higher risk of infection.

Therefore, mutual understanding and taking care of those who may have encountered prejudice or discrimination play an important role.

To answer the question: Does a crisis situation, such as COVID-19, change the set of norms and values that have so far been in force in the studied companies? It can be concluded that the crisis situation caused by COVID-19 has often forced companies to change the norms and values previously in force in order to survive and adapt to the pandemic. This situation could also have contributed to a better understanding and increased emphasis on creating a workplace that is friendly to those who bear parental or caring responsibilities. The current conditions for working from home, with flexible hours, now make it easier for parents to return to work e.g. part-time, using the available technology to connect with colleagues in the office. It also becomes an opportunity to increase the accessibility of jobs for new groups, including persons with disabilities.

Will the so-called "new normal" bring a new organisational culture after the pandemic? It is clear that the current pandemic will leave its mark on society, that the "new 
normal" will be different from the situation before the pandemic. However, despite the negative changes in many aspects, it may also contribute to some positive effects, such as a change in the attitude towards the employees through greater empathy and understanding, increased tolerance of flexible working hours or the creation of an organisational culture in which diversity, integration and belonging become the priorities.

Is organisational culture still important in a pandemic? In answer to this question, we can say that it plays a key role in crisis situations, including a pandemic. Building it in the era of coronavirus is particularly important because the involvement of employees, their cooperation and identification with the company allow for good change management and help the company to survive a difficult period. The fact that organisational culture is also important for employers is evidenced by the results of a survey conducted by Qmatch, on 800 employees of various companies from all over Poland, employed in various positions for at least six months. According to them, for the Polish employee, the employer's values, and opportunities for development and self-fulfilment are the most important, and the salary amount was demonstrated to be more important than organisational culture only for $33 \%$ of the surveyed employees (https://www.pulshr.pl ).

What changes enforced in companies by the current COVID-19 situation will remain for a longer period? The most important changes include the transition to remote work, the implementation of better technologies to improve mobile work, the increase of the proficiency of employees in new technologies, new workplace arrangements adapted to the situation or a change in the approach towards the employees.

In the current, dynamically changing reality, nothing has affected the way many companies operate as much as the current pandemic. The transition to remote work, replacing teamwork with virtual work, using virtual tools results in the employees being increasingly more proficient in various technological solutions. Also, the previously mentioned values such as empathy, understanding, tolerance take on a different value. These changes also result in innovations in the organisational culture of companies.In conclusion, it can be said that all the hypotheses put forward in this study have been verified positively.

\section{CONCLUSION}

One of the key characteristics of crisis situations is the fact that they appear suddenly, usually unexpectedly. This was the case with the COVID-19 pandemic, which was a litmus test for the organisational cultures of multiple companies. A crisis situation, including a pandemic, is a time when companies can check whether they actually implement their declared values. They can also try and set new values, which they will gradually implement. This requires the introduction of a number of actions to help the company change the model of its organisational culture. However, it should be noted that changing the organisational culture is a long-term process and requires great consistency.

\section{REFERENCES}

Ismail Al-Alawi, A., Yousif Al-Marzooqi, N. and Fraidoon Mohammed, Y. 2007. Kultura organizacyjna $i$ dzielenie się wiedzą: krytyczne czynniki sukcesu. Journal of Knowledge Management, 11 (2), 22-42, DOI: 10.1108/13673270710738898 
Allvesson, M, Berg, P.O., 1992. Foretags kulturoch organisationsymbolism, Utveckling, teoretiska perspective ochaktuelldebat, Studentlitteatur, Lund.

Blau, P.M,. 1968. Organizations, Theories, in: Sills, D.L. (ed.), International Encyclopedia of Social Sciences, McMillan, New York.

Czerska, M., 2003. Zmiana kulturowa w organizacji. Wyzwanie dla współczesnego menedżera, Wyd. Difin, Warszawa.

Deshapande, R., Parasurman, R., 1987. Linking Corporate Culture to Strategic Planning, Business Horizons, 29.

Felipe, C.M., Roldán, J.L., Leal-Rodríguez, A.L., 2017. Impact of Organizational Culture Values on Organizational Agility, Sustainability, 9 (12), 2354, DOI: 10.3390/su9122354

Hofstede, G., 2000. Kultury i organizacje. Zaprogramowanie umysłu, PWE, Warszawa.

Jemielniak, D., 2002. Kultura - odkrywana czy konstruowana?, Master of Business Administration, 2 (55).

Kisielnicki, J. 2005. Zarządzanie organizacją. Zarządzanie nie musi być trudne, wyd. 2, Oficyna Wydawnicza Wyższej Szkoły Handlu i Prawa im. R. Łazarskiego, Warszawa.

Kostera, M, 1996. Postmodermizm w zarządzaniu, Wyd. PWE, Warszawa, 60 -61.

Kostera, M., Śliwa, M., 2010. Zarządzanie w XXI wieku. Jakość. Twórczość. Kultura, Wydawnictwa Akademickie i Profesjonalne, Warszawa.

Koźmiński, A.K., Piotrowski, W., 1999. Zarządzanie. Teoria i praktyka, Wyd. PWN, Warszawa.

Kożusznik, B., 2011. Zachowania człowieka w organizacji, Polskie Wydawnictwo Ekonomiczne, Warszawa.

Lundy, M. O., Bowling, A., 2001. Strategiczne zarządzanie. Koncepcje i metody, Wydawnictwo Akademii Ekonomicznej im. o. Langego we Wrocławiu, Wrocław.

Maanen, J.V., 1988. Tales of the Field. On Writing Ethnography, University of Chicago Press, Chicago.

Martins, E.C., Terblanche, F. 2003. Building organisational culture that stimulates creativity and innovation, European Journal of Innovation Management, 6 (1), 6474. DOI: $10.1108 / 14601060310456337$

Pettigrew, A.M. 1979. On studying organizational cultures, Administrative Science Ouartely vol. 24.

Ravasi, D., Schultz, M. 2006. Responding to organizational identity threats: Exploring the role of organizational culture, Academy of Management Journal, 49 (3), 433458. DOI: 10.5465/AMJ.2006.21794663

Sikorski, C., 1988. Projektowanie i rozwój organizacji instytucji, Państwowe Wydawnictwo Ekonomiczne, Warszawa.

Schein, E.H., 1992. Organizational Culture and Leadership, Jossey-Bass, San Francisco.

Schenplein, H., 1988. Kultura przedsiębiorstwa i jej rozwój, Organizacja i Kierowanie, $7 / 8$.

Stańczyk, S., 2008. Nurt kulturowy w zarządzaniu, Wydawnictwo Uniwersytetu Ekonomicznego we Wrocławiu, Wrocław.

Zafer Acar, A., Pınar Acar, 2012. The effects of organizational culture and innovativeness on business performance in healthcare industry, Procedia - Social and Behavioral Sciences, 58, $683-692$. 
https://www.ican.pl/b/kultura-organizacji-w-kryzysie-czy-warto-cos-z-tymzrobic/PGuf3yXi0 (retrieved on: 29.08.2020)

https://poradnikprzedsiebiorcy.pl/-jakie-znaczenie-dla-firmy-ma-kultura-organizacyjna (retrieved on: 29.08.2020)

https://www.pulshr.pl/zarzadzanie/pieniadze-to-nie-wszystko-kultura-organizacyjnanabiera-znaczenia,73971.html (retrieved on: 09.09.2020) 